\title{
Nutritional composition, glycemic index and glycemic load on Indonesian local package menus
}

\author{
1,3, ${ }^{*}$ Hakimah, N., ${ }^{2}$ Yunus, M., ${ }^{3}$ Sucipto, S., ${ }^{3}$ Wignyanto, W. and ${ }^{4}$ Aulanni'am, A. \\ ${ }^{1}$ Department of Nutrition, Politeknik Kesehatan Kemenkes Malang, Malang, East Java, Indonesia \\ ${ }^{2}$ STMIK PPKIA Pradnya Paramita, Malang, Indonesia \\ ${ }^{3}$ Department of Agroindustrial Technology, Faculty of Agricultural Technology, Universitas \\ Brawijaya, Malang, East Java, Indonesia \\ ${ }^{4}$ Biochemistry Laboratory, Faculty of Sciences, Universitas Brawijaya, Malang, East Java, \\ Indonesia
}

\begin{abstract}
Article history:
Received: 10 November

2019

Received in revised form: 16

December 2019

Accepted: 18 December

2019

Available Online: 4 January

2020
\end{abstract}

\section{Keywords:}

Nutritional value,

Glycemic index,

Glycemic load,

Local package menu,

Red rice

\section{DOI:}

https://doi.org/10.26656/fr.2017.4(3).377

\begin{abstract}
This study was aimed to examine energy, density, proximate, dietary fiber and macronutrients ratio on the glycemic index and glycemic load of 6 kinds Indonesian local package menus made of red rice as a staple food and several other potentially antidiabetic food ingredients. The design was a quasi-experimental with 20 participants each of which were10 non-diabetic subjects ( 4 males and 6 females) aged between $20.3 \pm 1.0$ years old and 10 subjects with type 2 diabetes ( 5 males and 5 females) aged between $54.4 \pm 9.3$ years old. The results showed test package menu 1 (nasi liwet) has glycemic index and glycemic load can be accepted as healthy menu package in both, non-diabetic subjects (glycemic index $=23.8 \pm 9.2$; glycemic load $=11.9 \pm 4.6$ ) and diabetes subjects (glycemic index $=$ $17.5 \pm 8.5$; glycemic load $=8.7 \pm 3.3$ ). There is a moderate to a strong negative correlation between glycemic index and the incremental area under the curve with the content of protein, fat, total dietary fiber, soluble dietary fiber, and moderate to strong positive correlation with macronutrients ratio. In conclusion, prevention of increased postprandial blood glucose in the management of type 2 diabetes mellitus diet can be done by preparing a local Indonesian menu package based on red rice food ingredients by considering the type of menu, protein, fat, total and soluble dietary fiber, and macronutrient ratio.
\end{abstract}

\section{Introduction}

Carbohydrate foods with a low glycemic response and nutritional interventions become one of the strategies to optimize postprandial glycemia and proved useful in the dietary management of chronic diseases such as diabetes. Rice as the main food of half the world's population, is deemed an important food because it has implications for human nutrition and health. Around 122 countries in the world produce rice. China is the largest producer country in the first rank, followed by India, Indonesia, Thailand, Philippines, Vietnam and Bangladesh to supply $50 \%$ of the world (FAOSTAT, 2009).

The hundreds of types of rice in the world, such as accidentally consumed by the husk to get the nutrients and fiber are more, such as red rice because it is procured without going through the milling process, but it is simply milled into red rice so that the husk is still attached to the endosperm. Red rice husk is rich in natural oils, essential fats and fiber. The cuticle layer of the red rice known to have a content of $95 \%$ mineral consisting of iron, sodium, potassium, zinc, manganese, magnesium, selenium, phosphorus and molybdenum. The inside of red rice contains protein ranged from $9.9 \%$ to $14.0 \%$ (Gealy and Bryant, 2009), carbohydrates $73.7 \%$ to $79.3 \%$ (Sompong et al., 2011) and fat $2.2 \%$ to $3.7 \%$ (Yoshida et al., 2010). Red rice is also a source of fiber. Per $100 \mathrm{~g}$ red rice contains $13 \%$ of the fiber-based on the recommended daily intake. The content of dietary fiber in red rice than white rice 3.5 times (Zhou et al., 2002). Red rice was chosen in this study because compared to white rice, red rice is richer in nutrients, fiber and bioactive components but is low in glycemic index value and glycemic load (Imam et al., 2012; Kozuka et al., 2015).

A low-fiber diet and high glycemic index lead to sudden increases in blood sugar and increase the risk of 
developing Type 2 diabetes mellitus doubled from a high -fiber diet and low glycemic index (Schulze et al., 2004). A high-fiber diet is associated with a lower risk of type 2 diabetes. Therefore, based on higher dietary fiber content, with a relatively low glycemic index of 41 in brown rice may have a protective effect against the incidence of type 2 diabetes mellitus.

Total phenol and flavonoid content of red rice is also very high with their bioactive components that serve as antioxidants, anthocyanins and proanthocyanins which are concentrated in a layer of chaff role in inhibiting the activity of $\alpha$-amylase and $\alpha$-glucosidase (Hargrove et al., 2011; Yilmazer-Musa et al., 2012). Anthocyanins, a type of water-soluble pigment flavonoids, phytonutrients are found exclusively in plants. Flavonoids of this type can lower blood glucose by improving insulin resistance, increase insulin secretion, protect $\beta$ cells, and reducing sugar digestion in the small intestine. That adults consume at least $15 \%$ anthocyanins are less likely to develop type 2 diabetes mellitus (Wedick et al., 2012). Red rice became one of the best options for the staple food that can be consumed in the long term and the implications on health.

Traditional Indonesian food is one of the most dynamic cuisines, full of colors and flavors in the world because it comes from food that varies with herbs of various mixtures spices that diverse. Indonesia has about 5,350 local recipes and 30 of which are considered the most important. This study used 6 types of local food commonly consumed by Indonesian people, including: liwet rice, fried rice, grilled rice, manado porridge, gadogado cake rice, and cwiemie (IPFS, 2014). This study was aimed to examine energy, density, proximate, dietary fiber and macronutrients ratio on the glycemic index and glycemic load of 6 kinds Indonesian local package menus made of red rice as a staple food and several other potentially antidiabetic food ingredients.

\section{Materials and methods}

\subsection{Participants and approval of research ethics}

This study used two types of subjects, 10 subjects with controlled diabetes, consisting of 5 males and 5 females and 10 non-diabetic subjects, consisting of 4 males and 6 females. Both types of subjects signed informed consent. The series of this study already obtained agreement from the Ethics Committee of the Health Ministry of Republic of Indonesia, Health Polytechnic, Malang, East Java Province - Indonesia based on the recommendations of ethics approval Reg. No: 193/KEPK-POLKESMA/2017.

\subsection{Test meals}

The meals studied were in the form of a complete food package menu made from red rice as a staple food, with the standard recipe of Indonesia selected from IPFs Indonesian dishes as many as 6 types of packages, namely: nasi liwet, nasi goreng, nasi bakar, bubur manado, lontong gado-gado and cwiemie. Package menu consists of several local food ingredients which was potentially antidiabetic, red rice as the main ingredients, animal protein (cork fish, eggs), vegetable protein (tofu, tempeh, peanuts, soybeans), various vegetables (beans, moringa leaves, broccoli, bean sprouts, cucumber, carrot, tomato), supported by complementary food (green beans, guava, dragon fruit, green banana, avocado, lemon, mulberry leaves and cinnamon). All of the foodstuffs are obtained from traditional markets in Malang City, East Java Province, Indonesia.

\subsection{Nutritional value analysis}

The moisture and ash were tested by the oven method (AOAC, 2005; method 930.15). Protein was determined with the Kjeldahl method, expressed in $\mathrm{g} / 100$ $\mathrm{g}$ sample (AOAC International; method 981.10). Fat carried out with the Soxhlet method (AOAC International; method 991.36), expressed in $\mathrm{g} / 100 \mathrm{~g}$ sample. All determination of the moisture, ash, protein and fat using the standard methods of AOAC, 2005. Carbohydrates and calories were analyzed by different. Analysis of total, soluble and insoluble dietary fibers are conducted by enzymatic-gravimetric method (AOAC; method 985.29).

\subsection{Determination of the glycemic index (GI)}

GI value of meals was determined by giving glucose standard and test package menu on 2 types of subjects. Tests of subjects started in the morning after 12 hours overnight fasting. The blood samples of fasting subjects were taken at $0 \mathrm{~min}$; then the subject consumed standard glucose (dextrose monohydrate glucose) which was equivalent to 25-50 g carbohydrate content dissolved in $250 \mathrm{~mL}$ of water, and test meals in a separate time but completed the consumption within 15 mins. All tests, both on glucose standard and test meals were consumed which was served with $250 \mathrm{~mL}$ drinking water. Further, blood samples were taken at minute $30,60,90$, and 120 minutes after eating. Test meals consumed in a random order, with a distance of at least one day between the measurements to minimize carry-over effects of previous meals.

Blood sampling obtained from a finger prick using a lancet sterile medical GEA, and one touch Ultrasoft Lancing Device (Life Scan Johnson and Johnson Co.). 
The third finger on the left-hand side selected for use as a finger-stick blood sampling. Prior to prick fingers, the subjects were asked to warm their hands to increase blood flow. Blood plasma was taken as $0.6 \mathrm{ml}$ and blood glucose levels were measured using an automatic analyzer glucometer (One Touch Ultra TM Life Scan Johnson and Johnson Co.).

\subsection{Calculation of the glycemic index (GI) and glycemic load $(G L)$}

The Incremental Area Under the Curve (IAUC) was calculated geometrically by ignoring the area below the baseline (Broun set al., 2005). IAUC for each test meals consumed by each subject expressed as a percentage of the mean area of the incremental below the response curve of blood glucose (IAUC) for standard food consumed by the same subject, with the following formula:

$\mathrm{GI}=$ (IAUC for test meals containing 25-50 $\mathrm{g}$ of carbohydrate / IAUC standard food with the same carbohydrate portion) $\times 100$.

GI of each test meals was considered as the mean value of the whole group of subjects. GI classification was based on low GI value 1-55, 56-69 medium GI value, high GI value $\geq 70$

Glycemic Load (GL) was calculated based on the formula:

$\mathrm{GL}=(\mathrm{GI}$ test meals $\times$ amount of carbohydrates in servings test meals $(\mathrm{g}) / 100$

GL classification is based on the low $\mathrm{GL}=1-10$, medium $=11-19$, and high $\geq 20$

\subsection{Statistical analysis}

Based on Brouns et al. (2005), the number of samples used to the glycemic index test in this study were 10 subjects in each sample type, either on the subject of diabetes and subjects without diabetes that makes it possible to achieve degree of power and accuracy with the strength of the confidence interval of $95 \%$ and a significance level of alpha 0.05 .

Statistical analysis was performed using SPSS 16.0 statistical package (Statistical Package for Social Sciences, IBM, Cary, NC, USA). One-way ANOVA and Kruskal Walls to determine differences in nutrient content variables, glycemic index and glycemic load were studied from six kinds of test package menu. Paired t-test was used to compare average and total of IAUC between standard food (glucose) with each test package of food menu and inter-test package menu on the two subjects (non-DM and DM). Pearson correlations were used to determine the relationship between variables studied of the six types of test package menus. Statistical significance was set at $p \leq 0.05$.

\section{Results}

\subsection{Chemical analysis of test meals of menus}

The results of observation of the substitution degree, water content, $\mathrm{pH}$ and viscosity of Subjects of the present study were selected based on specific inclusion criteria to assess the GI of package meals made from red rice as a staple food. In non-diabetic subjects: a normal body mass index (BMI) (18.5 to 24.9), normal fasting and random blood glucose levels $(<100$ and $<140 \mathrm{mg} /$ $\mathrm{dL}$ ) or no family history, and on the subject of diabetes, on the contrary, have fasting and random blood glucose levels abnormal, they have a family history of diabetes, but their blood sugar levels under control. All kinds of subjects were not being in a state hospital when study was done. The parameters were collected from study subjects, including age, height, weight, body mass index (BMI), waist circumference (WC), waist-hip ratio (WHR) and \% body fat. The physical characteristics of the subject of further research are presented in Table 1. Table 1 presents data for the 2 study subjects with significant differences in age. Data with age differences are not to be compared, but only to illustrate the value of the glycemic index and glycemic load obtained using these two subjects

Table 1. Physical characteristics of study subjects

\begin{tabular}{lcc}
\hline \multirow{2}{*}{ Characteristics } & Mean \pm SD & Mean \pm SD \\
\cline { 2 - 3 } & $\begin{array}{c}\text { Non diabetic subjects } \\
(\mathrm{n}=10)\end{array}$ & $\begin{array}{c}\text { Type 2 DM subject } \\
(\mathrm{n}=10)\end{array}$ \\
\hline Age (years) & $20.3 \pm 1.0$ & $54.4 \pm 9.3$ \\
Height (m) & $1.6 \pm 0.1$ & $1.6 \pm 0.1$ \\
Weight (kg) & $57.5 \pm 11.5$ & $66.6 \pm 12.4$ \\
BMI (kg/m2) & $22.2 \pm 4.0$ & $26.8 \pm 4.4$ \\
WC (cm) & $72.0 \pm 9.9$ & $96.1 \pm 9.0$ \\
WHR (cm) & $0.8 \pm 0.1$ & $1.0 \pm 0.1$ \\
BF $(\%)$ & $22.6 \pm 7.1$ & $34.4 \pm 8.1$ \\
\hline
\end{tabular}

$\mathrm{BMI}=$ body mass index, $\mathrm{WC}=$ waist circumference, $\mathrm{WHR}=$ waist hip ratio, $\mathrm{BF}=$ body fat

The first stage of this study was examining the variables involved in calculating the value of the GI, composition of energy content, proximate, dietary fiber and ratio of carbohydrate: protein: fat (lipid) of the test meals. Data of energy content, proximate, carbohydrate: protein: fat (lipid) ratio, total dietary fiber and soluble dietary fiber per $100 \mathrm{~g}$ of each test meal are presented in Table 2. There are many variations in the energy and proximate composition, ratio of carbohydrate: protein: fat (lipid), total dietary fiber and soluble dietary fiber were analyzed from test meals composition due to 
various constituent ingredient foods and processing techniques.

The lowest ash content $(0.5 \pm 0.0 \%)$ on test menu 5 (lontong gado-gado) and the highest $(1.0 \pm 0.0 \%)$ on test menu 3 (nasi bakar). The lowest carbohydrate content $(9.2 \pm 1.5 \%)$ on test menu 5 (lontong gado-gado) and the highest $(28.5 \pm 18.2 \%)$ on the test menu 6 (cwiemie). The lowest protein content $(1.8 \pm 0.7 \%)$ on test menu 6 (cwiemie) and the highest $(4.7 \pm 0.8 \%)$ on test menu 1 (nasi liwet). The lowest fat content was $0.9 \pm 1.2 \%$ for test meal 4 (bubur manado) and the highest fat content $(4.7 \pm 0.9 \%)$ for test menu 5 (lontong gado-gado). Ratio of carbohydrate: protein: fat varied, starting from the lowest ratio on the test menu 5 (lontong gado-gado) to the highest ratio on the test menu 6 (cwiemie). Analysis of total dietary fiber content, the lowest was $3.7 \pm 0.4 \%$ for test meal 5 (bubur manado) and the highest $(10.5 \pm 0.8 \%)$ for test menu 1 (nasi liwet). The lowest soluble fiber content was $0.5 \pm 0.0 \%$ for test menu 3 (nasi bakar) and test menu 5 (lontong gado-gado) and the highest $1.3 \pm 0.1 \%$ for test menu 2 (nasi goreng). Based on menu type, preparation method and nutrient composition, there were significant differences in total dietary fiber content from the tested food package menu $(p=0.000)($ Table 2$)$.

\subsection{Value GI and GL}

GI Tests are based on 25-50 $\mathrm{g}$ of available carbohydrate in each test meal, defined as total carbohydrates minus dietary fiber in total. The obtained GI value varies according to the number of carbohydrates available in each package menu. Standard food (glucose) was also tested by using the equivalent amount of 25-50 g carbohydrates. The lowest to highest serving weight from the test menu ranges from $220 \mathrm{~g}$ (cwiemie) to $900 \mathrm{~g}$ (nasi liwet).

The value, and GI, GL classifications of six test meals are illustrated in Table 3 . These results indicate GI, and GL values of six test meals ranged from the lowest (nasi liwet) to the highest (cwiemie). GI value on

Table 2. Analysis of energy content, proximate, macronutrient ratio, and dietary fiber content of six types of package menus based on red rice as a staple food (per $100 \mathrm{~g}$ cooked weight)

\begin{tabular}{lccccccccc}
\hline $\begin{array}{c}\text { Test Meals } \\
\text { Package Menu }\end{array}$ & $\begin{array}{c}\text { Energy } \\
(\% \mathrm{kcal})\end{array}$ & $\begin{array}{c}\text { Water } \\
(\%)\end{array}$ & $\begin{array}{c}\text { Ash } \\
(\%)\end{array}$ & $\begin{array}{c}\text { Carbohydrate } \\
(\%)\end{array}$ & $\begin{array}{c}\text { Protein } \\
(\%)\end{array}$ & $\begin{array}{c}\text { Lipid } \\
(\%)\end{array}$ & $\begin{array}{c}\text { Ratio CHO:P:L } \\
(\% \text { of energy })\end{array}$ & $\begin{array}{c}\text { Total } \\
\text { Dietary } \\
\text { Fiber } \\
(\%)\end{array}$ & $\begin{array}{c}\text { Soluble } \\
\text { Dietary } \\
\text { Fiber } \\
(\%)\end{array}$ \\
\hline Nasi liwet (1) & $123.5 \pm 4.9$ & $75.0 \pm 0.9$ & $0.7 \pm 0.0$ & $16.1 \pm 1.1$ & $4.7 \pm 0.8$ & $4.5 \pm 1.4$ & $52: 15: 33$ & $10.5 \pm 0.8$ & $1.0 \pm 0.0$ \\
Nasi goreng (2) & $118.5 \pm 26.2$ & $74.6 \pm 6.0$ & $0.7 \pm 0.0$ & $17.8 \pm 5.6$ & $2.9 \pm 0.1$ & $4.0 \pm 0.4$ & $60: 10: 30$ & $6.6 \pm 0.7$ & $1.3 \pm 0.1$ \\
Nasi bakar (3) & $101.0 \pm 4.2$ & $76.9 \pm 0.9$ & $1.0 \pm 0.0$ & $16.3 \pm 0.6$ & $3.1 \pm 0.1$ & $2.6 \pm 0.1$ & $65: 12: 23$ & $6.9 \pm 1.0$ & $0.5 \pm 0.0$ \\
Bubur manado (4) & $74.0 \pm 21.2$ & $81.9 \pm 4.0$ & $0.8 \pm 0.1$ & $14.3 \pm 2.5$ & $2.2 \pm 0.3$ & $0.9 \pm 1.2$ & $77: 12: 11$ & $3.7 \pm 0.4$ & $0.7 \pm 0.1$ \\
Lontong gado- & $94.0 \pm 1.4$ & $81.9 \pm 1.4$ & $0.5 \pm 0.0$ & $9.2 \pm 1.5$ & $3.8 \pm 0.8$ & $4.7 \pm 0.8$ & $39: 16: 45$ & $5.9 \pm 0.5$ & $0.5 \pm 0.0$ \\
gado (5) & $141.0 \pm 70.7$ & $66.7 \pm 17.6$ & $0.8 \pm 0.0$ & $28.5 \pm 18.2$ & $1.8 \pm 0.7$ & $2.2 \pm 0.1$ & $81: 05: 14$ & $5.4 \pm 0.9$ & $1.2 \pm 0.0$ \\
Cwiemie (6) & 0.221 & 0.251 & 0.077 & 0.345 & 0.067 & 0.087 & 0.008 & 0.000 & 0.043 \\
p-value & & & & & & & & & \\
\hline
\end{tabular}

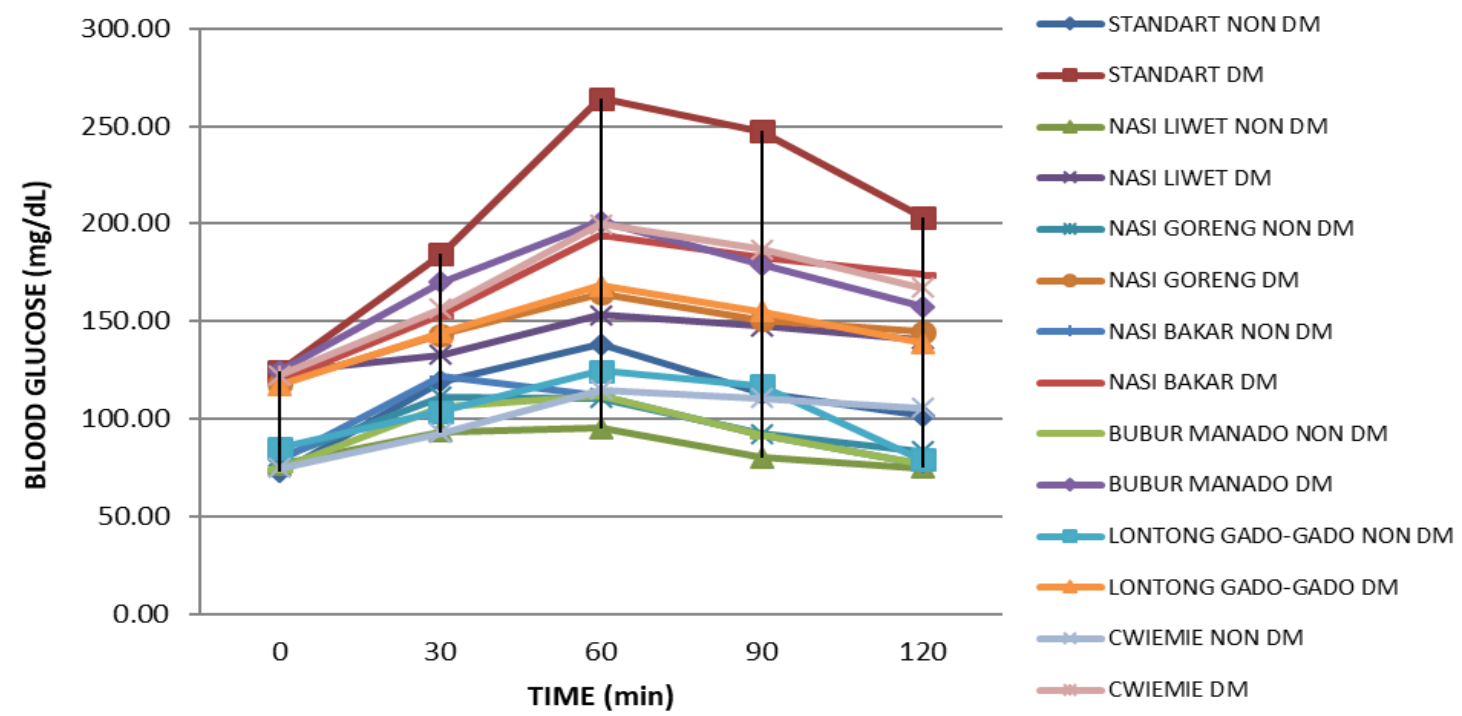

Figure 1. Incremental area under the curve of blood glucose for the glucose standard and the six of test packages menus on nondiabetes mellitus (Non-DM) subjects and diabetes mellitus (DM) subjects 
Table 3. Values of glycemic index (GI), glycemic load (GL), and classifications of six test meal package menus based on serving size

\begin{tabular}{|c|c|c|c|c|c|c|c|c|c|}
\hline \multirow{3}{*}{$\begin{array}{l}\text { Test Meals } \\
\text { Package Menu }\end{array}$} & \multirow{3}{*}{$\begin{array}{l}\text { Serving } \\
\text { Size (g) }\end{array}$} & \multicolumn{2}{|c|}{ Glycemic Index (GI) } & \multicolumn{2}{|c|}{ Classification GI } & \multicolumn{2}{|c|}{ Glycemic Load (GL) } & \multicolumn{2}{|c|}{ GL Classification } \\
\hline & & Subjects & Subjects & Subjects & Subjects & Subjects & Subjects & Subjects & Subjects \\
\hline & & Non DM & DM & Non DM & $\mathrm{DM}$ & Non DM & $\mathrm{DM}$ & Non DM & $\overline{D M}$ \\
\hline$\overline{\text { Nasi liwet (1) }}$ & 900 & $23.8 \pm 9.3$ & $17.5 \pm 8.5$ & Low & Low & $11.9 \pm 4.6$ & $8.7 \pm 3.3$ & Medium & Low \\
\hline Nasi goreng (2) & 450 & $44.8 \pm 19.3$ & $28.8 \pm 10.9$ & Low & Low & $22.4 \pm 9.7$ & $14.4 \pm 2.8$ & High & Medium \\
\hline Nasi bakar (3) & 535 & $54.5 \pm 18.6$ & $48.6 \pm 17.5$ & Low & Low & $27.3 \pm 9.3$ & $24.3 \pm 3.5$ & High & High \\
\hline Bubur manado (4) & 475 & $53.5 \pm 14.7$ & $57.6 \pm 18.0$ & Low & Medium & $26.8 \pm 7.4$ & $28.8 \pm 9.0$ & High & High \\
\hline Lontong gado-gado (5) & 750 & $53.8 \pm 20.5$ & $38.6 \pm 14.1$ & Low & Low & $26.9 \pm 10.3$ & $19.3 \pm 7.1$ & High & Medium \\
\hline Cwiemie (6) & 220 & $65.7 \pm 19.7$ & $60.3 \pm 19.6$ & Medium & Medium & $32.8 \pm 9.9$ & $30.1 \pm 9.8$ & High & high \\
\hline p-value & & 0.000 & 0.000 & & & 0.000 & 0.000 & & \\
\hline
\end{tabular}

non-DM subjects from $23.8 \pm 9.3$ to $65.7 \pm 19.7$, and $17.5 \pm 8.5$ to $60.3 \pm 19.7$ on DM subjects. All of the GI classification rang were considered low up to medium. Whereas, the value of six GL test meals ranged from $11.9 \pm 4.6$ to $32.8 \pm 9.9$ in non-DM subjects and between $8.7 \pm 3.3$ to $30.1 \pm 9.8$ in DM subjects, with GL classifications ranged from low to high. GI and GL values of all test package menus had significant differences $(p=0.000)$.

The Incremental Area Under Curve (IAUC) for standard food (glucose) and test meals of package menus shown in Figure 1. The difference between the glucose response of tested food was analyzed using paired t-test. The maximum increase in blood glucose (MIBG) and total IAUC between standard glucose and all of the test meals had significant differences $(p<0.000)$. Similarly, MIBG and total IAUC between all of test package menus on both subjects (non-DM and DM) had significant differences $(p \leq 0.05)$.

\subsection{The correlation between nutritional composition, GI and IAUC of test package menus}

There were negative correlation between GI and IAUC with the energy content (weak correlation), energy density (very weak-weak correlation), moisture (weak correlation), protein (moderate-strong correlation), fat (moderate-strong correlation), total dietary fiber (moderate-strong correlation), soluble dietary fiber (weak-moderate correlation) and serving size (weak correlation). Conversely, there was a positive correlation with the content of the ash (very weak-weak correlation) and carbohydrates (weak correlation), and macronutrients ratio (moderate-strong correlation) in the test package menus based on red rice as a staple food. Energy density from the test package menu correlates positively and strongly with soluble fiber $(r=0.804)$. The humidity level of the test package menu has a strong and positive correlation with the protein content $(\mathrm{r}=$ 0.815 ). The total dietary fiber test package menus were strongly positively correlated $(r=0.992 ; r=0.919)$ with insoluble fiber and protein, The correlations were shown in Table 4.

\section{Discussion}

\subsection{Chemical analysis of test meals of menus}

Identifying the food glycemic response mechanism in the body is not as easy as measuring the glycemic response. Based on the increase in the maximum blood

Table 4. Correlation between nutritional composition, glycemic index value, and IAUC of the six test package menus

\begin{tabular}{lcccc}
\hline \multirow{2}{*}{ Nutrient content } & \multicolumn{2}{c}{ Glycemic Index } & \multicolumn{2}{c}{ IAUC } \\
\cline { 2 - 5 } & Pearson's r (p-Value) & Pearson's r (p-Value) & Pearson's r (p-Value) & Pearson's r (p-Value) \\
\cline { 2 - 5 } & Non-DM Subject & DM Subject & Non-DM Subject & DM Subject \\
\hline Energy & $-0.261(0.618)$ & $-0.256(0.625)$ & $-0.276(0.597)$ & $-0.299(0.565)$ \\
Energy Density & $-0.085(0.873)$ & $-0.222(0.672)$ & $-0.075(0.888)$ & $-0.227(0.665)$ \\
Moisture & $-0.213(0.686)$ & $-0.129(0.808)$ & $-0.246(0.638)$ & $-0.176(0.738)$ \\
Ash & $0.014(0.978)$ & $0.245(0.640)$ & $0.024(0.964)$ & $0.384(0.452)$ \\
Carbohydrates (CHO) & $0.215(0.682)$ & $0.333(0.518)$ & $0.226(0.666)$ & $0.312(0.547)$ \\
Protein (P) & $-0.674(0.142)$ & $-0.654(0.158)$ & $-0.701(0.121)$ & $-0.662(0.152)$ \\
Fat (L) & $-0.528(0.282)$ & $-0.696(0.124)$ & $-0.561(0.247)$ & $-0.742(0.091)$ \\
Ratio CHO:P:L & $0.646(0.166)$ & $0.757(0.081)$ & $0.662(0.152)$ & $0.665(0.150)$ \\
Total Dietary Fiber & $-0.727(0.102)$ & $-0.662(0.152)$ & $-0.741(0.092)$ & $-0.634(0.177)$ \\
Soluble Dietary Fiber & $-0.349(0.498)$ & $-0.297(0.567)$ & $-0.344(0.504)$ & $-0.413(0.415)$ \\
Serving Size & $-0.201(0.703)$ & $-0.110(0.835)$ & $-0.232(0.659)$ & $-0.160(0.762)$ \\
\hline
\end{tabular}

Correlation strength category as very weak (0-0.1), weak (0.1-0.3), moderate (0.4-0.6), strong (0.7-0.9) and perfect (1.0) 
glucose and total IAUC, all of test package menus differed significantly with the standard food $(p=0.000)$ and the results of one-way ANOVA led to the type of package menus significantly affect the GI and GL, either on non-DM and DM subjects $(p=0.000)$. The results of this study are supported by the research of Hakimah et al. (2019) previously which showed that except for the time reach peak blood glucose (TPGB), there were differences in all glycemic response variables on red rice diet menu with reference food. Several studies described that a combination of some foods could affect the GI and lower the glycemic response (Henry et al., 2006). The result of Pearson correlation test obtained negative correlation between GI and GL with the energy density, moisture, protein, fat and dietary fiber, and there was positive correlation with the ash content, carbohydrates and macronutrients ratio (carbohydrate: protein: fat), both on the subject non-DM and DM subjects.

The energy density is expressed as energy (kcal) / weight portion (g) negatively correlated with GI and GL, but with the level of strength of the correlation was deemed weak. Energy density from the test package menu which correlates positively and strongly with soluble fiber can explain why they have a negative correlation with GI and GL, because, with the increase of energy density of test package menus in this study, the content of dietary fiber was also increased, especially for soluble food fiber. Results of another study also explained that the increased consumption of viscous soluble fibers has a great effect on the reduction in glycemic response but limit palatability (Wolever et al., 1999). The mixture of viscous fiber significantly lowers the glycemic index of foods by $74 \%$ in healthy participants and 63\% for those with diabetes (Livesey and Tagami, 2008). Research Jenkins et al. (2008) showed a decrease in IAUC commonly consumed foods in healthy subjects when $5 \mathrm{~g}$ New Viscous Polysaccharide (NVP) was added. This study contradicts that of Brand Ludwig and Miller stating that the selection of food with a GI and a low energy density was done with the aim to control blood sugar levels (Ek et al., 2012).

All food package menus tested have different moisture levels, although they were not significant. The test food package menu consists of almost the same main and complementary ingredients; however, composition, method and preparation time are different, which affects the differences in the level of gelatinization of starch which results in GI values. Methods of heat, humidity, and cooking be factors that could affect the level of gelatinization of GI starchy foods (Ek et al., 2012). It was observed mainly in the preparation of test package menu 3 (nasi bakar), menu 4 (bubur manado), menu 5 (lontong gado-gado), and menu 6 (cwiemie), had a GI value, IAUC and GL higher, both on the subjects of nonDM and DM. In this study, the moisture level of the test package menu also has a strong and positive correlation with its protein content because it is influenced by the composition of the ingredients and the preparation method. The cooking process was done on those fourth test package menus involves the amount of water more to finalize cooking of ingredient foods and containing a mixture of vegetable protein primarily, such as green beans in roasted rice.

In addition, methods of preparation for the test package menu 4 (bubur manado) and 5 (lontong gadogado), involve a long cooking time (about 3 hours) for all of the material with water at high temperatures. High temperature and the cooking time increased in a large amount of water associated with a higher degree of gelatinization of starch and digestibility, as well as an increase in blood glucose levels (Ek et al., 2012). Food starch particle size so especially affects the GI, the smaller or smooth affected easier hydrolyzed of enzymes in the digestive system and increased GI, as happened in the test package menu 6 (cwiemie) with the major constituent food-based material derived from red rice that was pressed.

\subsection{Value GI and GL}

A lower GI value on nasi liwet might also be caused by the composition of the main constituent of food ingredients and its complementary, as well as methods of preparation. The material composition of the test menu 1 (nasi liwet) produces a ratio of macronutrient and total dietary fiber significantly different from other test menus. The method of preparation by steaming red rice on the menu of test 1 (nasi liwet) produces the effect of a lower GI than other methods of preparation. The method of preparation by steaming provides optimum heat treatment for red rice in a minimum time of about 24 minutes to get an acceptable texture. Preparation of steaming red rice in this kind of way generates a response rate of digestion and blood glucose more slowly (Lehmann and Robin, 2007). The ash content contained in the test package menu but weakly positively correlated with GI, IAUC, and GL. In line with these results, it was found no significant effect of ash content in rice varieties with GI (Gosby et al., 2011).

Differences in chemical composition and physiochemical contribute to the different GI effects of red rice than milled rice in general. In general, two kinds of rice have content of starch granules consisting of two fractions, namely amylose and amylopectin. Higher amylose content in red rice than white rice caused its digestibility to become slower because amylose is a 
polymer of glucose that has not branched structure is more crystalline hydrogen bonding, which is more extensive that much more difficult to be hydrolyzed by digestive enzymes. Chew and Vinoy (2017) also explained that the level of appearance of $\mathrm{CHO}$ from cereal products containing slow digestive starch caused a glycemic response and postprandial insulin response more slowly. The structure that does not branch out from amylose makes it bound more strongly so that it is also difficult to occur gelatinization. The content of resistant starch (RS) in red rice also proved to be higher (Nugent, 2005). Resistant starch is a starch fraction which is not hydrolyzed into D-glucose in the small intestine within 120 minutes after consumption but is fermented in the large intestine (Raigond et al., 2015). RS rate could have an effect on reducing or slowing digestion level which implicates controlling the levels of glucose in the blood.

In this study, total dietary fiber test menu packages made from red rice staple foods were strongly positively correlated with insoluble fiber and protein, and medium negative correlations on GI, IAUC and GL DM both type subjects. The percentage of insoluble fiber content in each test package menu was generally greater than the soluble fiber content. In the test menu package 1 (nasi liwet) had the highest content of total dietary fiber and significant differences from total dietary fiber content of another test package menu, resulting in the value of GI and GL IAUC lowest. The existence of a higher dietary fiber in red rice can affect spike in blood glucose levels rise and contribute to a low GI value. Fiber acts to slow the rate of food in the digestive tract and inhibits the activity of the enzyme so that the process of digestion in particular starch becomes slower and the blood glucose response will be lower. In red rice starch substrate, to some extent, digestive enzymes could still not activate which indicated by lower levels of digestibility due to their physically blocked bran components. This is in line with studies conducted in healthy individuals and individuals with diabetes that fractions of rice bran can reduce the glycemic response (Qureshi et al., 2002).

GI values are not only influenced by the size of the absorption of carbohydrates in person at the time in the small intestine but can also be influenced by other factors. Protein and fat content in foods containing carbohydrates have the potential to reduce the glycemic response and lower the overall GI value. The mechanism of nutrient content affects blood glucose concentrations that have been described in many studies. It appears from the observations, protein and fat content of test package menu 1 (nasi liwet) is relatively higher than other test package menus and its macronutrient ratio limits as required by the American Diabetes Association (Evert et al., 2014). All kind of package menu consists of the main foods are similar, namely: red rice, cork fish, eggs, processed soy products, beans and moringa leaves, which are known to have a high protein content. High protein content produces gastric acid inhibitor peptide/ gastric inhibitory peptide (GIP) and insulin responses in lower postprandial glucose peak thus lowering the glycemic response and GI foods (Hätönen et al., 2011). In the short-term, high protein diet seems to also have a beneficial effect on weight loss, body composition, and certain blood lipids (Evert et al., 2014). Lowering the percent of protein in the diet from $10 \%$ to $15 \%$ can increase total energy intake, so then the intake of foods containing higher protein can help reduce energy intake (Hession et al., 2011).

The addition of protein and fat content higher potentially also against the slowing of gastric emptying so that slow digestion and absorption of glucose then continues to a reduction in glycemic response. However, fat also affects the interaction of plasma glucose, insulin, and GIP. Fat is a powerful stimulant of GIP secretion. GIP plasma peak value of the high-fat meal $(450 \mathrm{kcal}$ and $33.3 \%$ fat) is three times higher than the $75 \mathrm{~g}$ oral glucose tolerance in human subjects (Yamane et al., 2016).

The macronutrient ratio (carbohydrate: protein: fat or lipid) produced from the test food package menus in this study differed significantly and was positively correlated and was categorized as moderate to strong with GI, IAUC and GL. This balanced macronutrient ratio makes it possible to achieve glycemic control and other normal metabolic outcomes. Macronutrient composition on carbohydrates $(40-60 \%)$, protein $(20 \%)$, fat $(<30 \%)$ (Evert et al., 2014). Test package menu 1 (nasi liwet) was a package menu that has a ratio or composition of content macronutrient that most closely with the requirements recommended, GI and GL of nasi liwet were including low and medium category, both on nonDM and DM subjects. The results of this study are consistent with research Meng et al. (2017) who revealed that the main food macronutrient composition affects the glycemic response and the determination of the value of GI and GL foods.

\section{Conclusion}

All types of Indonesian local food test package menus based on staple foods from red rice already had a GI in the low to moderate category. GI and GL which have met low to moderate loads, either in non-diabetic or diabetic subjects are contained in the test package menu 1 (nasi liwet). Protein, fat, macronutrient ratio, total dietary fiber and food preparation methods correlate with GI. The test package menu 1 (nasi liwet) as Indonesian 
local food has the most balanced macronutrient ratio and the highest total food fiber produces a lower of glycemic index and glycemic load. The results in this study can be findings that can be further developed to produce a variety of package menus with compositions that are preferred and can be applied as daily lifestyles in the long term, thus becoming a preventive, curative and rehabilitative step in anticipating a surge in postprandial blood glucose, especially in the management of type 2 diabetes mellitus diets.

\section{Conflict of Interest}

The authors declare no conflict of interest.

\section{Acknowledgments}

This work was a part of a dissertation research submitted to the Department of Agro Industrial Technology, Brawijaya University of Malang. The researchers would like to thank the Ministry of Health of the Republic of Indonesia for supporting this research, and all parties, including peer review: External and Internal peer review.

\section{References}

Brouns, F., Bjorck, I., Frayn, K.N., Gibbs, A.L., Lang, V., Slama, G. and Wolever, T.M.S. (2005). Glycaemic index methodology. Nutrition Research Reviews, 18(1), 145-171. https://doi.org/10.1079/ NRR2005100

Chew, P.G. and Vinoy, S. (2017). Slowly digestible starch from cereal-based foods, metabolic interest at breakfast presented at 1st Southeast Asia Public Health Nutrition Conference in conjunction with Nutrition Society of Malaysia $32^{\text {nd }}$ Annual Scientific Conference, May 14-17, 2017. Malaysia: Southeast Asia Public Health Nutrition Network.

Ek, K.L., Brand-Miller, J. and Copeland, L. (2012). Glycemic effect of potatoes. Food Chemistry, 133 (4), 1230-1240. https://doi.org/10.1016/ j.foodchem.2011.09.004

Evert, A.B., Boucher, J.L., Cypress, M., Dunbar, S.A., Franz, M.J., Mayer-Davis, E.J. and Yancy, W.S. (2014). Nutrition therapy recommendations for the management of adults with diabetes. Diabetes Care, 37(Suppl. 1), S120-S143. https://doi.org/10.2337/ dc14-S120

FAOSTAT. (2009). FAO statistics division 2012. Retrieved on August 7, 2019 from FAO website http://ref.data.fao.org/dataset-data-filter? entryId $=527 \mathrm{c} 6170$-a842-4926-95ed$9 \mathrm{dd} 1 \mathrm{~b} 800436 \mathrm{~d} \& \mathrm{tab}=$ data.
Gealy, D.R. and Bryant, R.J. (2009). Seed physicochemical characteristics of field-grown US weedy red rice (Oryza sativa) biotypes: Contrasts with commercial cultivars. Journal of Cereal Science, 49(2), 239-245. https://doi.org/10.1016/ j.jcs.2008.10.007

Gosby, A.K., Conigrave, A.D., Lau, N.S., Iglesias, M.A., Hall, R.M., Jebb, S.A. and Simpson, S.J. (2011). Testing protein leverage in lean humans: a randomised controlled experimental study. PloSOne, 6(10), e25929. https://doi.org/10.1371/ journal.pone. 0025929

Hakimah, N., Yunus, M., Sucipto, S., Wignyanto, W. and Aulanni'am, A. (2019). The Comparison of Diet Menu Quality Based on Red Rice as a Staple Food Using Glycemic Response Variables. Indian Journal of Forensic Medicine and Toxicology, 13(4), 15571562.

https://doi.org/10.5958/0973-

9130.2019 .00524 .3

Hargrove, J.L., Greenspan, P., Hartle, D.K. and Dowd, C. (2011). Inhibition of aromatase and $\alpha$-amylase by flavonoids and proanthocyanidins from Sorghum bicolor bran extracts. Journal of Medicinal Food, 14 (7-8), 799-807. https://doi.org/10.1089/ jmf.2010.0143

Hätönen, K.A., Virtamo, J., Eriksson, J.G., Sinkko, H.K., Sundvall, J.E. and Valsta, L.M. (2011). Protein and fat modify the glycaemic and insulinaemic responses to a mashed potato-based meal. British Journal of Nutrition, 106(2), 248-253. https://doi.org/10.1017/ S0007114511000080

Henry, C.J.K., Lightowler, H.J., Kendall, F.L. and Storey, M. (2006). The impact of the addition of toppings/fillings on the glycaemic response to commonly consumed carbohydrate foods. European Journal of Clinical Nutrition, 60(6), 763. https:// doi.org/10.1038/sj.ejen.1602380

Hession, M., Rolland, C., Kulkarni, U., Wise, A. and Broom, J. (2009). Systematic review of randomized controlled trials of low-carbohydrate vs. low-fat/lowcalorie diets in the management of obesity and its comorbidities. Obesity Reviews, 10(1), 36-50. https:// doi.org/10.1111/j.1467-789X.2008.00518.x

IPFS. (2014). Indonesian Cuisine. Retrieved on July 21, 2019 from Website: https://ipfs.io/ipfs/ QmXoypizjW3WknFiJnKLwHCnL72vedxjQkDDP1 $\mathrm{mXWo6uco/wiki/Indonesian \_ cuisine.html.}$

Imam, M.U., Musa, S.N.A., Azmi, N.H. and Ismail, M. (2012). Effects of white rice, brown rice and germinated brown rice on antioxidant status of type 2 diabetic rats. International journal of molecular sciences, 13(10), 12952-12969. https:// doi.org/10.3390/ijms 131012952 
Kozuka, C., Sunagawa, S., Ueda, R., Higa, M., Tanaka, H., Shimizu-Okabe, C., Ishiuchi, S., Takayam, C., Matshushita, M., Tsutsui, M., Miyazaki, J., Oyadomari, S., Shimabukuro, M. and Masuzaki, H. (2015). $\gamma$-Oryzanol protects pancreatic $\beta$-cells against endoplasmic reticulum stress in male mice. Endocrinology, 156(4), 1242-1250. https:// doi.org/10.1210/en.2014-1748

Jenkins, A.L., Jenkins, D.J.A., Wolever, T.M.S., Rogovik, A.L., Jovanovski, E., Božikov, V., Rahelic, D. and Vuksan, V. (2008). Comparable postprandial glucose reductions with viscous fiber blend enriched biscuits in healthy subjects and patients with diabetes mellitus: acute randomized controlled clinical trial. Croatian Medical Journal, 49(6), 772-782. https:// doi.org/10.3325/cmj.2008.49.722

Lehmann, U. and Robin, F. (2007). Slowly digestible starch-its structure and health implications: a review. Trends in Food Science and Technology, 18(7), 346355. https://doi.org/10.1016/j.tifs.2007.02.009

Livesey, G. and Tagami, H. (2008). Interventions to lower the glycemic response to carbohydrate foods with a low-viscosity fiber (resistant maltodextrin): meta-analysis of randomized controlled trials. The American Journal of Clinical Nutrition, 89(1), 114125. https://doi.org/10.3945/ajcn.2008.26842

Meng, H., Matthan, N.R., Ausman, L.M. and Lichtenstein, A.H. (2017). Effect of prior meal macronutrient composition on postprandial glycemic responses and glycemic index and glycemic load value determinations. The American Journal of Clinical Nutrition, 106(5), 1246-1256. https:// doi.org/10.3945/ajen.117.162727

Nugent, A.P. (2005). Health properties of resistant starch. Nutrition Bulletin, 30(1), 27-54. https:// doi.org/10.1111/j.1467-3010.2005.00481.x

Qureshi, A.A., Sami, S.A. and Khan, F.A. (2002). Effects of stabilized rice bran, its soluble and fiber fractions on blood glucose levels and serum lipid parameters in humans with diabetes mellitus Types I and II. The Journal of Nutritional Biochemistry, 13 (3), 175-187. https://doi.org/10.1016/S0955-2863 (01)00211-X

Raigond, P., Ezekiel, R. and Raigond, B. (2015). Resistant starch in food: a review. Journal of the Science of Food and Agriculture, 95(10), 1968-1978. https://doi.org/10.1002/jsfa.6966

Schulze, M.B., Liu, S., Rimm, E.B., Manson, J.E., Willett, W.C. and Hu, F.B. (2004). Glycemic index, glycemic load, and dietary fiber intake and incidence of type 2 diabetes in younger and middle-aged women. The American Journal of Clinical Nutrition, 80(2), 348-356. https://doi.org/10.1093/ ajen/80.2.348

Sompong, R., Siebenhandl-Ehn, S., Linsberger-Martin, G. and Berghofer, E. (2011). Physicochemical and antioxidative properties of red and black rice varieties from Thailand, China and Sri Lanka. Food Chemistry, 124(1), 132-140. https://doi.org/10.1016/ j.foodchem.2010.05.115

Wedick, N.M., Pan, A., Cassidy, A., Rimm, E.B., Sampson, L., Rosner, B. and van Dam, R.M. (2012). Dietary flavonoid intakes and risk of type 2 diabetes in US men and women. The American Journal of Clinical Nutrition, 95(4), 925-933. https:// doi.org/10.3945/ajen.111.028894

Wolever, T.K., Foster-Powell, M. and Colagiuri, S. (1999). The Glucose Revolution: The Authoritative Guide to the Glycemic Index-The Groundbreaking Medical Discovery. New York: Marlowe and Company.

Yamane, S., Harada, N. and Inagaki, N. (2016). Mechanisms of fat-induced gastric inhibitory polypeptide/glucose-dependent insulinotropic polypeptide secretion from $\mathrm{K}$ cells. Journal of Diabetes Investigation, 7(S1), 20-26. https:// doi.org/10.1111/jdi.12467

Yilmazer-Musa, M., Griffith, A.M., Michels, A.J., Schneider, E. and Frei, B. (2012). Grape seed and tea extracts and catechin 3-gallates are potent inhibitors of $\alpha$-amylase and $\alpha$-glucosidase activity. Journal of Agricultural and Food Chemistry, 60(36), 89248929. https://doi.org/10.1021/jf301147n

Yoshida, H., Tomiyama, Y. and Mizushina, Y. (2010). Lipid components, fatty acids and triacylglycerol molecular species of black and red rices. Food Chemistry, 123(2), 210-215. https://doi.org/10.1016/ j.foodchem.2010.04.010

Zhou, Z., Robards, K., Helliwell, S. and Blanchard, C. (2002). Composition and functional properties of rice. International Journal of Food Science and Technology, 37(8), 849-868. https://doi.org/10.1046/ j.1365-2621.2002.00625.x 